\title{
Hizenite-( $\mathrm{Y}), \mathrm{Ca}_{2} \mathrm{Y}_{6}\left(\mathrm{CO}_{3}\right)_{11} \cdot 14 \mathrm{H}_{2} \mathrm{O}$, a new mineral in alkali olivine basalt from Mitsukoshi, Karatsu, Saga Prefecture, Japan
}

\author{
Yasuhiro TAKAI ${ }^{*}$ and Seiichiro UEHARA \\ Department of Earth and Planetary Sciences, Faculty of Sciences, Kyushu University, \\ 6-10-1 Hakozaki, Higashi-ku, Fukuoka 812-8581, Japan \\ *Present Affiliation: Enecom Co., Ltd.
}

\begin{abstract}
Hizenite-(Y), ideal formula $\mathrm{Ca}_{2} \mathrm{Y}_{6}\left(\mathrm{CO}_{3}\right)_{11} \cdot 14 \mathrm{H}_{2} \mathrm{O}$, occurs in druse of alkali olivine basalt at Mitsukoshi, Karatsu, Saga Prefecture, Japan. It occurs as a platy crystal and forms spherical aggregates. Hizenite-(Y) closely associates with lokkaite-(Y), tengerite-(Y), and kimuraite-(Y). It is orthorhombic, $a=6.295(1) \AA, b=9.089(2) \AA$, $c=63.49(1) \AA, V=3632(1) \AA^{3}, Z=4$. Hizenite-(Y) is white in color with vitreous to silky luster. The density is $2.98 \mathrm{~g} / \mathrm{cm}^{3}$ (calc), and there is a perfect cleavage on $\{001\}$. The strongest lines in the X-ray powder diffraction pattern are $\left[d\left(I / I_{0}\right) h k l\right] 10.63(100) 006,6.384(77) 0 \cdot 0 \cdot 10,3.962(51) 0 \cdot 0 \cdot 16,3.821(27) 029,1 \cdot 0 \cdot 13,2.060(23)$ $306,0 \cdot 4 \cdot 13,15.57(20) 004$.
\end{abstract}

Keywords: Hizenite-(Y), Mitsukoshi, Higashimatsuura basalt, New mineral

\section{INTRODUCTION}

During a mineralogical investigation of rare earth (RE) minerals in the alkali olivine basalt, Mitsukoshi, Karatsu, Saga Prefecture, Japan, a white druse mineral was identified in the alkali olivine basalt. The occurrence of the mineral is similar to that of tengerite-(Y) and lokkaite$(\mathrm{Y})$, but the $\mathrm{X}$-ray powder diffraction pattern and chemical composition showed it to be a new hydrous $\mathrm{Ca}-\mathrm{Y}$ carbonate. The lattice parameters and chemical composition of the mineral showed that it is a member of tengerite family.

The name 'Hizen' is for the classic country name of the locality of the mineral. It had existed in northwest Kyushu (Saga and Nagasaki Prefecture) since the 7th century to the 16th century, and now, it remains as the name of town in Karatsu city. The mineral and mineral name have been approved by the International Mineralogical Association, Commission on New Minerals, Nomenclature and Classification (No. 2011-30). The type specimen is deposited in Kitakyushu Museum of Natural History and Human History, Kitakyushu, Japan, under the registered number KMNHM000001.

doi:10.2465/jmps.120925

Y. Takai, takai@kyudai.jp

S. Uehara, uehara@geo.kyushu-u.ac.jp Corresponding author

\section{OCCURRENCE}

Hizenite-(Y) occurs in a small druse in the alkali olivine basalt at Mitsukoshi, Karatsu, Saga Prefecture, Japan, called the Higashimatsuura basalt. This locality is the type locality of kozoite-(La) (Miyawaki et al., 2003). The Higashimatsuura basalt is a Neogene alkali olivine basalt and consists of five stages, based on volcanic activities (Ishibashi, 1971). The most recent stage has yielded three new minerals: kimuraite-(Y) (Nagashima et al., 1986),

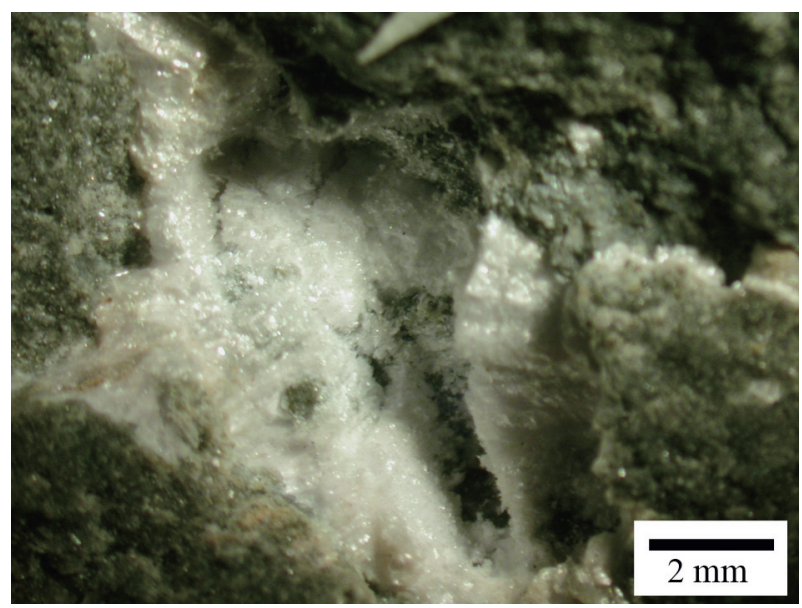

Figure 1. Micrograph of hizenite- $(\mathrm{Y})$ showing its occurrence mode. 
kozoite-(Nd) (Miyawaki et al., 2000) and kozoite-(La).

Hizenite-(Y) occurs in a small platy crystal (25-50 $\mu \mathrm{m}$ in size, $0.04-0.2 \mu \mathrm{m}$ in thickness), forming radial aggregates up to $1 \mathrm{~cm}$ in druse (Figs. 1 and 2). Hizenite-(Y) usually closely associates with lokkaite-(Y), tengerite(Y) and kimuraite-(Y).

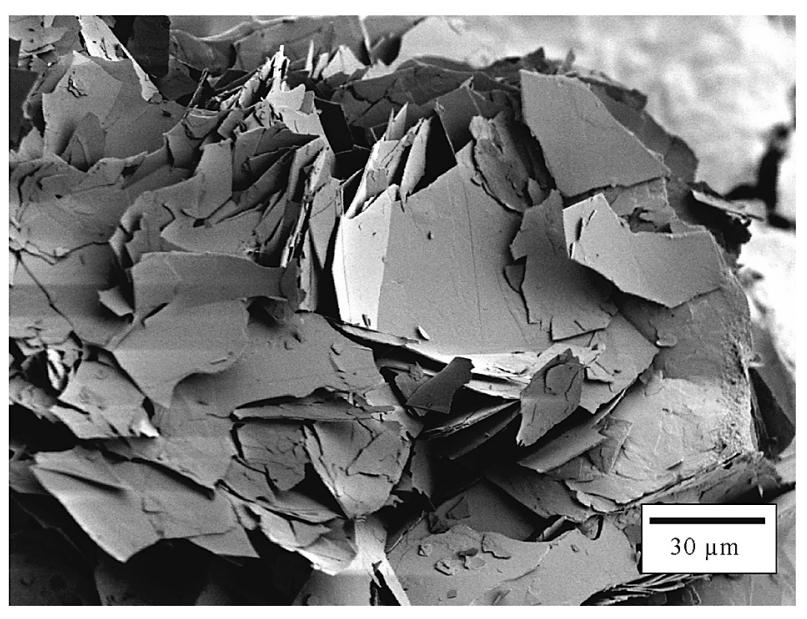

Figure 2. Secondary electron image of hizenite-(Y).

\section{OPTICAL AND PHYSICAL PROPERTIES}

Hizenite-(Y) is white in color and translucent to transparent. It has vitreous to silky luster on the cleavage plane which is perfect on $\{001\}$. The streak is white. The calculated density is $2.98 \mathrm{~g} / \mathrm{cm}^{3}$. Because of the small size of the mineral, the other optical and physical properties could not be measured.

\section{CHEMICAL COMPOSITION}

Quantitative chemical analysis was carried out using a scanning electron microscope with energy dispersive $\mathrm{X}$ ray spectroscopy (SEM-EDS; JEOL JSM-5800LV, Oxford ISIS, $20 \mathrm{kV}$ and $0.5 \mathrm{nA}$ ). The content of $\mathrm{H}_{2} \mathrm{O}$ and $\mathrm{CO}_{2}$ were analyzed by a CHN analyzer (Perkin Elmer 2400 II) in Kitakyushu Museum of Natural history and Human history. The analysis was carried out in five points and the results of analysis are given in Table 1 . The empirical formula, on the basis of $47 \mathrm{O}$ structural atoms, is $\mathrm{Ca}_{1.76}\left(\mathrm{Y}_{4.08}\right.$ $\mathrm{Nd}_{0.58} \mathrm{Gd}_{0.35} \mathrm{Dy}_{0.28} \mathrm{Sm}_{0.16} \mathrm{Er}_{0.14} \mathrm{La}_{0.11} \mathrm{Pr}_{0.07} \mathrm{Eu}_{0.07} \mathrm{Ho}_{0.04} \mathrm{~Tb}_{0.02}$ $\left.\mathrm{Yb}_{0.01} \mathrm{Tm}_{0.00}\right)_{\Sigma 5.91}\left(\mathrm{CO}_{3}\right)_{11.2} \cdot 13.9 \mathrm{H}_{2} \mathrm{O}$, and the simplified and ideal formulae are $\mathrm{Ca}_{2}(\mathrm{Y}, \mathrm{Nd}, \mathrm{Gd}, \mathrm{Dy})_{6}\left(\mathrm{CO}_{3}\right)_{11} \cdot 14 \mathrm{H}_{2} \mathrm{O}$ and $\mathrm{Ca}_{2} \mathrm{Y}_{6}\left(\mathrm{CO}_{3}\right)_{11} \cdot 14 \mathrm{H}_{2} \mathrm{O}$, respectively.
Table 1. Chemical composition of hizenite-(Y)

\begin{tabular}{crcc}
\hline $\mathrm{n}=5$ & \multicolumn{1}{c}{$w$ t $\%$} & \multicolumn{1}{c}{ Range } & No. atoms $(\mathrm{O}=47)$ \\
\hline $\mathrm{Y}_{2} \mathrm{O}_{3}$ & 27.61 & $26.20-29.60$ & 4.08 \\
$\mathrm{La}_{2} \mathrm{O}_{3}$ & 1.11 & $0.95-1.41$ & 0.11 \\
$\mathrm{Pr}_{2} \mathrm{O}_{3}$ & 0.65 & $0.00-0.89$ & 0.07 \\
$\mathrm{Nd}_{2} \mathrm{O}_{3}$ & 5.80 & $4.69-6.72$ & 0.58 \\
$\mathrm{Sm}_{2} \mathrm{O}_{3}$ & 1.68 & $1.04-1.97$ & 0.16 \\
$\mathrm{Eu}_{2} \mathrm{O}_{3}$ & 0.73 & $0.00-1.56$ & 0.07 \\
$\mathrm{Gd}_{2} \mathrm{O}_{3}$ & 3.82 & $2.85-4.70$ & 0.35 \\
$\mathrm{~Tb}_{2} \mathrm{O}_{3}$ & 0.24 & $0.00-0.79$ & 0.02 \\
$\mathrm{Dy}_{2} \mathrm{O}_{3}$ & 3.10 & $2.75-3.54$ & 0.28 \\
$\mathrm{Ho}_{2} \mathrm{O}_{3}$ & 0.47 & $0.00-0.93$ & 0.04 \\
$\mathrm{Er}_{2} \mathrm{O}_{3}$ & 1.58 & $1.02-1.83$ & 0.14 \\
$\mathrm{Tm}_{2} \mathrm{O}_{3}$ & 0.04 & $0.00-0.22$ & 0.00 \\
$\mathrm{Yb}_{2} \mathrm{O}_{3}$ & 0.10 & $0.00-0.51$ & 0.01 \\
& & & \\
$\mathrm{CaO}_{2}$ & 5.93 & $5.28-6.42$ & 1.76 \\
$\mathrm{CO}_{2}$ & 29.55 & $28.78-30.32$ & 11.21 \\
$\mathrm{H}_{2} \mathrm{O}$ & 15.03 & $14.85-15.21$ & 27.88 \\
\hline $\mathrm{Total}$ & 97.44 & & \\
\hline
\end{tabular}

\section{CRYSTALLOGRAPHY}

Single-crystal X-ray diffraction studies could not be carried out because of the small crystal-size. Unit cell parameters were determined from electron diffraction pattern observed by a transmission electron microscope (TEM). X-ray powder diffraction pattern was indexed using these cell parameters, and refined it.

TEM analysis data were obtained using a JEOL 200CX microscope (Kyushu University HVEM Laboratory). The electron diffraction pattern observed from normal to the cleavage plane showed periodicities of $6.3 \AA$ (100) and $9.1 \AA$ (010) (Fig. 3). Furthermore, the electron diffraction pattern observed from parallel to the cleavage plane showed a periodicity of $63.7 \AA$ (001). The specimen was prepared using a focused ion beam (FIB) in Kyushu University HVEM Laboratory. The simulated diffraction pattern conforms closely to the observation data (Fig. 4). The simulated model was assumed that alternated layer structure consists of kimuraite-(Y) and lokkaite-(Y) on one to one relation along the $c$ axis (Fig. 5). The single crystal structure analyses of kimuraite-(Y) and lokkaite(Y) have not been made, but those models are estimated from the chemical composition and cell parameters (Miyawaki and Nakai, 1987). Kimuraite-(Y) consists of an $\mathrm{Y}$-corrugated sheet and a $\mathrm{Ca}-\mathrm{H}_{2} \mathrm{O}$ layer on one to one relation along the $c$ axis, and lokkaite-(Y) consists of two to one relation. On the simulated model of hizenite- $(\mathrm{Y})$, the $\mathrm{Ca}-\mathrm{H}_{2} \mathrm{O}$ layer was simplified because there are no detailed models on kimuraite-(Y) and lokkaite-(Y), and the $\mathrm{Y}$-corrugated sheet was referred the crystal structure of tengerite-(Y) (Miyawaki and Matsubara, 2004).

Powder X-ray diffraction data (Table 2) were ob- 
tained using a diffractometer (BRUKER AXS M18XHF22-SRA, MXP18) with $\mathrm{CuK \alpha}$ radiation generated at $40 \mathrm{kV}$ and $100 \mathrm{~mA}$, and monochromated with graphite. The reflections of hizenite-(Y) could be indexed with an orthorhombic cell, but the space group could not be determined. A preferred orientation effect due to the perfect $\{001\}$ cleavage is present. The unit cell parameters refined from the powder data: $a=6.295(1), b=9.089(2), c$ $=63.49(1) \AA, V=3632(1) \AA^{3}$ and $Z=4$.

\section{RELATIONSHIP TO OTHER MINERALS}

Hizenite-(Y) is the member of tengerite family [tengerite(Y) (Miyawaki and Matsubara, 2004), kimuraite-(Y) and lokkaite-(Y) (Nagashima et al., 1986)]. The relationships of the lattice parameters, chemical formula and other data of those minerals are shown in Table 3. The dimensions of the $\boldsymbol{a}$ and $\boldsymbol{b}$ axes of hizenite-(Y) are similar to those of tengerite family minerals. Hizenite- $(\mathrm{Y})$ has an alternated structure of kimuraite-(Y) and lokkaite-(Y) on one to one relation along the $c$ axis (Fig. 5). This structure model was supported by the chemical formula of hizenite-(Y) which just between kimuraite-(Y) and lokkaite-(Y).
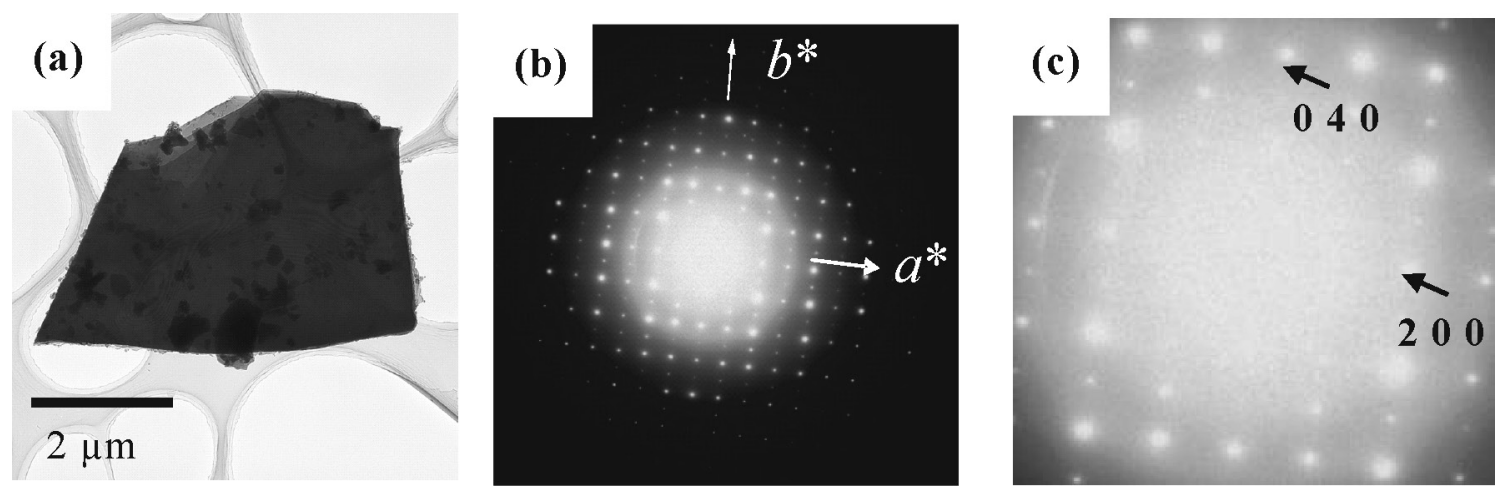

Figure 3. TEM image and electron diffraction pattern of hizenite-(Y) observed from normal to the cleavage plane $\{001\}$. (a) Bright field image. (b) Electron diffraction pattern observed from the $c$ axis. (c) Enlarged pattern of (b) with indications of index.
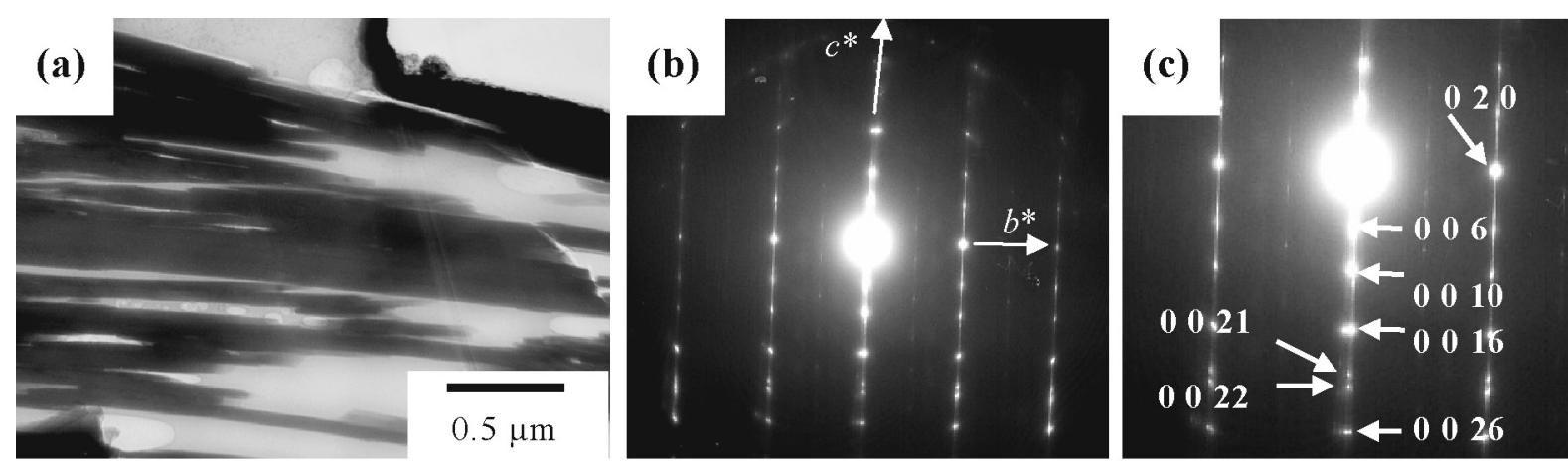

Figure 4. TEM image and electron diffraction pattern of hizenite-(Y) observed from parallel to the cleavage plane $\{001\}$. (a) Bright field image. (b) Electron diffraction pattern observed from the $\boldsymbol{a}$ axis. (c) Enlarged pattern of (b) with indications of index. (d) Simulated diffraction pattern. 
Table 2. X-ray powder diffraction data for hizenite-(Y)

\begin{tabular}{|c|c|c|c|c|c|c|c|}
\hline$h k l$ & $d_{\text {obs }} \AA$ & $d_{\text {calc }} \AA$ & $I / I_{0}$ & $h k l$ & $d_{\text {obs }} \AA$ & $d_{\text {calc }} \AA$ & $I / I_{0}$ \\
\hline & 19.62 & & $4^{*}$ & 3112 & \multirow{2}{*}{1.908} & 1.908 & \multirow{2}{*}{6} \\
\hline $\begin{array}{lll}0 & 0 & 4\end{array}$ & 15.57 & 15.86 & 20 & 323 & & 1.898 & \\
\hline $\begin{array}{lll}0 & 0 & 6\end{array}$ & 10.63 & 10.58 & 100 & $\begin{array}{lll}3 & 1 & 13\end{array}$ & \multirow{4}{*}{1.882} & 1.886 & \multirow{4}{*}{7} \\
\hline & 7.653 & & $5^{* *}$ & 1229 & & 1.882 & \\
\hline $\begin{array}{lll}0 & 0 & 10\end{array}$ & 6.384 & 6.346 & 77 & $\begin{array}{lll}0 & 1 & 33\end{array}$ & & 1.881 & \\
\hline & 5.873 & & 4 & $\begin{array}{lll}0419\end{array}$ & & 1.879 & \\
\hline & 4.630 & & 5 & 1325 & \multirow{3}{*}{1.857} & 1.859 & \multirow{4}{*}{1} \\
\hline $\begin{array}{lll}0 & 0 & 16\end{array}$ & 3.962 & 3.966 & 51 & $\begin{array}{lll}0 & 327\end{array}$ & & 1.857 & \\
\hline 029 & 3821 & 3.820 & 27 & 2318 & & 1.856 & \\
\hline $\begin{array}{lll}10 & 13\end{array}$ & 3.821 & 3.858 & 27 & 0420 & \multirow{3}{*}{1.845} & 1.848 & \\
\hline 123 & 3.632 & 3.631 & 2 & 2127 & & 1.844 & \multirow[t]{2}{*}{1} \\
\hline 127 & 3.411 & 3.414 & 1 & 240 & & 1.843 & \\
\hline & 3.230 & & $4^{*}$ & 050 & \multirow{4}{*}{1.818} & 1.818 & \multirow{4}{*}{2} \\
\hline & 3.010 & & $2^{*}$ & $\begin{array}{lll}0232\end{array}$ & & 1.818 & \\
\hline $\begin{array}{lll}1 & 0 & 19\end{array}$ & & 2.951 & & $\begin{array}{lll}0421\end{array}$ & & 1.816 & \\
\hline 213 & 2.946 & 2.946 & 9 & 246 & & 1.815 & \\
\hline 1213 & & 2.941 & & 247 & \multirow{2}{*}{1.801} & 1.806 & \multirow{2}{*}{0} \\
\hline 130 & & 2.730 & 1 & 1419 & & 1.801 & \\
\hline $\begin{array}{lll}10 & 21\end{array}$ & 2.724 & 2.724 & 1 & $\begin{array}{lll}0 & 0 & 36\end{array}$ & \multirow[t]{2}{*}{1.764} & 1.763 & \multirow[t]{2}{*}{3} \\
\hline $\begin{array}{lll}2110\end{array}$ & & 2.694 & & 1232 & & 1.747 & \\
\hline $\begin{array}{lll}0 & 2 & 19\end{array}$ & 2.692 & 2.692 & 1 & $\begin{array}{lll}3 & 1 & 19\end{array}$ & \multirow{4}{*}{1.741} & 1.744 & \multirow{4}{*}{3} \\
\hline 134 & & 2.691 & & 1035 & & 1.743 & \\
\hline $\begin{array}{lll}0 & 2 & 20\end{array}$ & 2.600 & 2.602 & 3 & 2322 & & 1.741 & \\
\hline 224 & & 2.554 & & 153 & & 1.741 & \\
\hline 1218 & 2.549 & 2.548 & 3 & 2227 & \multirow{3}{*}{1.679} & 1.740 & \multirow{3}{*}{2} \\
\hline 139 & & 2.546 & & 2032 & & 1.678 & \\
\hline $\begin{array}{lll}0 & 1 & 25\end{array}$ & \multirow{4}{*}{2.445} & 2.445 & & 1137 & & 1.628 & \\
\hline $\begin{array}{lll}0 & 0 & 26\end{array}$ & & 2.441 & & 2326 & \multirow{3}{*}{1.629} & 1.627 & \multirow{3}{*}{2} \\
\hline 0222 & & 2.436 & 16 & 1235 & & 1.627 & \\
\hline 1123 & & 2.435 & & $\begin{array}{lll}3 & 3 & 13\end{array}$ & & 1.627 & \\
\hline & 2.422 & & $3^{*}$ & 0429 & \multirow{8}{*}{1.573} & 1.576 & \\
\hline 1318 & 2.157 & 2.159 & 7 & $\begin{array}{lll}1 & 0 & 39\end{array}$ & & 1.576 & \\
\hline 238 & 2.103 & 2.105 & 1 & 250 & & 1.574 & \\
\hline $\begin{array}{lll}0 & 4 & 13\end{array}$ & \multirow{3}{*}{2.060} & 2.060 & & 400 & & 1.574 & \\
\hline 306 & & 2.059 & 23 & $\begin{array}{lll}4 & 0 & 1\end{array}$ & & 1.574 & 3 \\
\hline 308 & & 2.029 & & 2421 & & 1.573 & \\
\hline $\begin{array}{lll}3 & 14\end{array}$ & 2.027 & 2.028 & 2 & 403 & & 1.570 & \\
\hline 1410 & & 2.026 & & 404 & & 1.566 & \\
\hline $\begin{array}{lll}3 & 1 & 7\end{array}$ & & 1.995 & & 348 & & 1.514 & \\
\hline $\begin{array}{lll}3 & 0 & 10\end{array}$ & 1.995 & 1.993 & 1 & 1335 & 1.511 & 1.511 & 3 \\
\hline $\begin{array}{lll}0 & 0 & 32\end{array}$ & & 1.983 & & 0432 & & 1.494 & \\
\hline 1227 & & 1.982 & & 2425 & 1489 & 1.491 & 2 \\
\hline $\begin{array}{lll}318\end{array}$ & 1.980 & 1.980 & 4 & 1239 & 1.489 & 1.489 & 2 \\
\hline 2025 & & 1.976 & & 420 & & 1.487 & \\
\hline
\end{tabular}

${ }^{*}$ Lokkaite-(Y). ${ }^{* *}$ Tengerite-(Y). 
Table 3. Comparative data for tengerite family minerals

\begin{tabular}{ccccc}
\hline & Tengerite $^{*}$ & Lokkaite $^{* *}$ & Kimuraite $^{* *}$ & Hizenite this study \\
\hline Chemical formula & $\mathrm{Y}_{2}\left(\mathrm{CO}_{3}\right)_{3} \cdot 2-3 \mathrm{H}_{2} \mathrm{O}$ & $\mathrm{CaY}_{4}\left(\mathrm{CO}_{3}\right)_{7} \cdot 9 \mathrm{H}_{2} \mathrm{O}$ & $\mathrm{CaY}_{2}\left(\mathrm{CO}_{3}\right)_{4} \cdot 6 \mathrm{H}_{2} \mathrm{O}$ & $\mathrm{Ca}_{2} \mathrm{Y}_{6}\left(\mathrm{CO}_{3}\right)_{11} \cdot 14 \mathrm{H}_{2} \mathrm{O}$ \\
Crystal system & Orthorhombic & Orthorhombic & Orthorhombic & Orthorhombic \\
$a$ & 6.0815 & 6.104 & 6.0433 & 6.295 \\
$b$ & 9.1596 & 9.26 & 9.2545 & 9.089 \\
$c$ & 15.0956 & 39.35 & 23.976 & 63.49 \\
$\mathrm{Z}$ & 4 & 4 & 4 & 4 \\
V & 840.89 & 2224.18 & 1340.9 & 3632 \\
Density (obs) & 3.12 & 2.92 & 2.6 & 2.96 \\
Density (calc) & 3.11 & 2.92 & 2.98 & 2.98 \\
\hline
\end{tabular}

* Miyawaki and Matsubara., 2004. ${ }^{* *}$ Nagashima et al., 1986.

: Y-corrugated sheet

: $\mathrm{Ca}$ and $\mathrm{H}_{2} \mathrm{O}$ layer

$15.10 \AA$

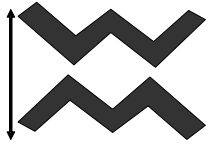

Tengerite

\section{$23.98 \AA$}

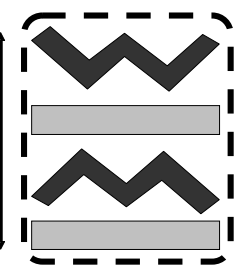

Kimuraite
$39.35 \AA$

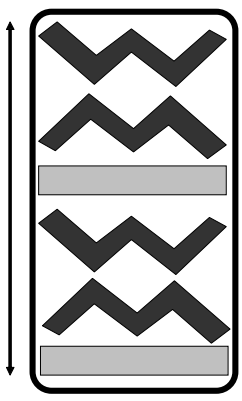

Lokkaite
$63.49 \AA$

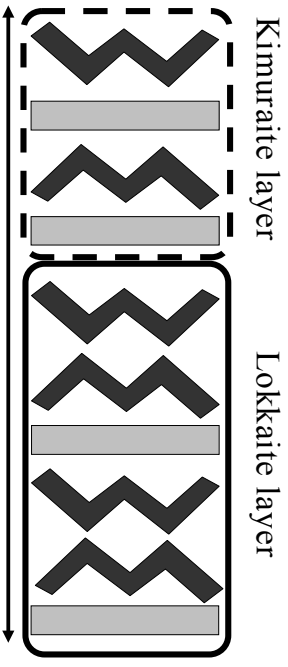

Hizenite
Figure 5. Schematic illustrations of the layer structure models of hizenite-(Y) and tengerite family minerals. These models of tengerite- $(\mathrm{Y})$, kimuraite- $(\mathrm{Y})$ and lokkaite-(Y) are modified from Miyawaki and Nakai (1987).

\section{ACKNOWLEDGMENTS}

The authors would like to thank Mr. S. Iwano for his assistance in the collecting specimens in field work. Special thanks are extended to Dr. Y. Mori of Kitakyushu Museum of Natural history and Human history for his analysis by the CHN analyzer and to Dr. M. Miyahara of Faculty of Science, Tohoku University for advice in FIB. Y. Takai appreciate Professor Tatsuro Matsumoto Scholarship Fund for assistance for field work of this study. We are also grateful to anonymous reviewers for their constructive and critical reviews of the manuscript.

\section{REFFERENCES}

Ishibashi, K. (1971) Petrochemical study of Basaltic rock from Higashimatsuura and Ikitsuki-jima District, Northern Kyushu, Japan. Science reports, Department of Geology, Kyushu University, 10, 177-221.

Miyawaki, R. and Nakai, I. (1987) Crystal Structures of Rare-
Earth Minerals. RARE EARTHS, 11, 9-11.

Miyawaki, R., Matsubara, S., Yokoyama, K., Takeuchi, K., Terada, Y. and Nakai, I. (2000) Kozoite-( $\mathrm{Nd}), \mathrm{Nd}\left(\mathrm{CO}_{3}\right)(\mathrm{OH})$, a new mineral in an alkali olivine basalt from Hizen-cho, Saga Prefecture, Japan. American Mineralogist, 85, 1076-1081.

Miyawaki, R., Matsubara, S., Yokoyama, K., Iwano, S., Hamasaki, K. and Yukinori, I. (2003) Kozoite-(La), $\mathrm{La}\left(\mathrm{CO}_{3}\right)(\mathrm{OH})$, a new mineral from Mitsukoshi, Hizen-cho, Saga Prefecture, Japan. Journal of Mineralogical and Petrological Sciences, 98, 137-141.

Miyawaki, R. and Matsubara, S. (2004) A Refinement of the Crystal Structure of Synthetic Tengerite-(Y). Bulletin of the National Science Museum Series C, 30, 1-4.

Nagashima, K., Miyawaki, R., Takase, J., Nakai, I., Sakurai, K., Matsubara, S., Kato, A. and Iwano, S. (1986) Kimuraite-(Y), $\mathrm{CaY}_{2}\left(\mathrm{CO}_{3}\right) \cdot 6 \mathrm{H}_{2} \mathrm{O}$, a new mineral from fissures in an alkali olivine basalt from Saga Prefecture, Japan, and new data on lokkaite-(Y). American Mineralogist, 71, 1028-1033.

Manuscript receved September 25, 2012

Manuscript accepted January 29, 2013

Published online May 2, 2013

Manuscript handled by Akira Yoshiasa 